\title{
Impact of Epidemiology on Molecular Genetics of Schizophrenia
}

\author{
Nagafumi Doi ${ }^{1}$, Yoko Hoshi ${ }^{2}$, Masanari Itokawa ${ }^{2}$, \\ Takeo Yoshikawa ${ }^{3}$ and Tomoe Ichikawa ${ }^{2}$ \\ ${ }^{1}$ Ibaraki Prefectural Medical Center of Psychiatry \\ ${ }^{2}$ Tokyo Metropolitan Institute of Medical Science \\ ${ }^{3}$ RIKEN Brain Science Institute \\ Japan
}

'To grasp the full meaning of the obvious is a better basis for the understanding than the confused knowledge of the obscure.'

(Engels)

\section{Introduction}

Schizophrenia is a common deleterious psychosis that begins typically in late adolescence or early adulthood (Gottesman, 1991; Jablensky, 1995). Although it has a strong genetic component in its etiology, no susceptibility genes conferring a large proportion of heritability have been identified (Allen et al., 2008; Need et al, 2009). Results of association studies including genome-wide scans have been inconsistent, and schizophrenia-associated genes including copy number variations differ across populations or even across individuals of a same ethnicity (Allen et al., 2008; Xu et al., 2008; Need et al, 2009). Thus, situation of molecular genetics of schizophrenia has become rather perplexing just contrary to our expectation.

In this chapter, we describe the consistent major epidemiological findings of schizophrenia, and show how these evident macroscopic aspects shed light to the confused microscopic aspects of schizophrenia genetics today, proposing a new hypothesis for this puzzling disorder.

\section{Devil's triangle of human genetics - Epidemiological facts of schizophrenia}

We describe here three epidemiological facts of schizophrenia - high prevalence, high heritability and low reproductive fitness. These properties form a Devil's triangle; any combination of the two tends to exclude the third, and in this triangle most diseases vanish except for schizophrenia, suggesting that schizophrenia has a unique etiological basis among the many human diseases.

\subsection{Schizophrenia as a common disease}

Substantial evidence of epidemiology shows that schizophrenia crosses all cultures and tribes in different continents at a relatively high prevalence (approximately $0.7 \%$; 95\% 
Confidence Interval $0.3 \%-2.7 \%$ ) (Saha et al., 2005); the prevalence of schizophrenia, at the macro-level, varies within narrow limits (Jablensky, 1995), and appears to be stable across generations in several countries (Harrison et al., 1991; Osby et al., 2001). This epidemiological fact suggests that schizophrenia has an ancient origin.

\subsection{Schizophrenia as a heritable disease}

It has long been known that schizophrenia runs in families (McGue \& Gottesman, 1991). Adoption studies demonstrate an increased risk of schizophrenia in biological relatives of adoptees with schizophrenia, suggesting that genetic components play an important role in the etiology of schizophrenia (Kendler \& Dichl, 1993). Now it has been established by twin studies that heritability of schizophrenia is $\sim 0.85$ (Cannon et al., 1998; Cardno et al., 1999).

Although the mode of transmission of schizophrenia is still unknown, several reports suggest a higher maternal transmission of schizophrenia (Shimizu et al., 1987; Goldstein et al., 1990; Valero et al., 1998; Li et al., 2007).

\subsection{Schizophrenia as a low fitness disease}

It has been well documented that the fertility of patients with schizophrenia, particularly of males, is remarkably reduced compared to healthy individuals (Böök, 1953; Larson \& Nyman, 1973; Ødegård, 1980; Nanko \& Moridaira, 1993; Fãnanás \& Bertranpetit, 1995; Nimgaonkar, 1998; McGrath et al., 1999; Haukka et al., 2003; Svensson et al., 2007). The latest meta-analysis (Bundy et al., 2011) shows that fertility ratio (patients/controls) is $\sim 0.39$ and that the reduction of fertility is more pronounced in males (male/female ratio is $\sim 0.54)$.

Because schizophrenia is an early onset disease (late adolescence $\sim$ early adulthood), psychotic symptoms of the disease such as autistic way of life and abnormal behaviors may make mating unsuccessful. This tendency may be more pronounced in males because the age at onset is significantly lower in males than in females (Jablensky, 1995; Kulkarni \& Fink, 2000). Thus, unsuccessful mating, coupled with an increased mortality (McGrath et al., 2008), may remarkably reduce the fertility of patients with schizophrenia.

\subsection{Schizophrenia and the Devil's triangle of human genetics}

The three epidemiological characteristics of schizophrenia - high prevalence, high heritability and low fitness - form a Devil's triangle; any combination of the two tends to exclude the third, and in this triangle most diseases vanish except for schizophrenia (Fig. 1). Diseases with high prevalence and high heritability such as type 2 diabetes and adult cancers are late-onset diseases and exhibit almost normal reproductive fitness. Diseases with high heritability and low reproductive fitness such as most harmful Mendelian diseases in childhood are rare. Diseases with low reproductive fitness and high prevalence such as poor nutrition, severe injuries and infections in childhood or early adulthood are mainly due to the environmental factors.

This may lead us to strongly suspect that schizophrenia has a unique etiological basis among the many human diseases. 


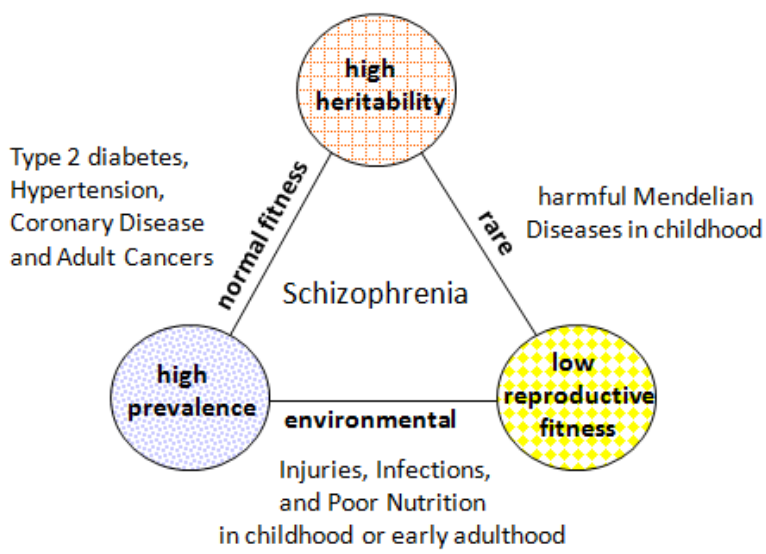

Fig. 1. Devil's triangle of human genetics (Doi et al., 2009)

\section{Persistence problem and mutation-selection balance in schizophrenia}

The three epidemiological characteristics of schizophrenia mentioned above give a paradox. How has a highly heritable disease associated with a remarkable biological disadvantage never been extinct in the long human history? And how can it persist at a relatively high prevalence? This 'persistence problem of schizophrenia' (or 'schizophrenia paradox') has puzzled scientists for long years (Huxley et al., 1964; Crow, 1995; Brüne, 2004; Keller \& Miller, 2006).

In this section, we discuss that the only plausible mechanism for the persistence is mutationselection balance with or without heterozygote advantage. Based on the consistent epidemiological findings on the fertility of patients with schizophrenia and their family members, we show that heterozygote advantage works in the mitochondrial genome model but not in the nuclear genome model.

\subsection{Mutation-selection balance is the only plausible mechanism for the persistence}

From an evolutionary viewpoint, four explanations are possible for the persistence: (i) ancestral neutrality, (ii) negative frequency-dependent selection, (iii) heterozygote advantage (balancing selection or pleiotropy), and (iv) mutation-selection balance.

'Ancestral neutrality' assumes that reproductive fitness of affected individuals and/or their relatives was higher in ancient environments and that selection coefficients of pathogenic alleles were close to zero. Because the effective population size in ancient times might be much smaller than now, pathogenic but neutral or almost neutral alleles could be fixed by genetic drift. While this hypothesis explains that schizophrenia has not been extinct in the long human history, ancestral neutrality itself provides no explanation for the apparently stable prevalence of the disease across generations today; although 'ancestral neutrality' might be plausible, it needs another mechanism to account for the persistence in modern environments, where the effective population size has been expanded and the influence of negative selection pressure may be much stronger than ever before. 
'Negative frequency-dependent selection' explains the persistence only when the fitness of the affected individuals increases as the prevalence in the general population decreases, which seems not to be the case with schizophrenia.

Thus, the remaining possibility for persistence mechanism is mutation-selection balance with or without heterozygote advantage.

\subsection{Heterozygote advantage works in the mitochondrial genome model but not in the nuclear genome model for schizophrenia}

'Heterozygote advantage' assumes that the susceptibility alleles increase the fitness of the unaffected gene carriers, thereby sustaining the gene frequencies. This line of explanations may include: (i) physiological advantage (resistance to shock, infections, and poor nutrition etc.), (ii) a higher sexual activity and/or attractiveness, and (iii) creative intelligence or a higher trait creativity including 'everyday creativity'.

This hypothesis needs two lines of confirmation: (a) that unaffected gene carriers have such advantages, and (b) that such advantages really contribute to sufficiently increase their reproductive fitness.

It seems to gain the confirmation (a). For example, Erlenmeyer-Kimling (1968) reported an increased survival rate of female children of parents with schizophrenia, proposing a possible physiological advantage associated with schizophrenia. Kinney et al. (2001), in a well-designed and methodologically sophisticated study, showed that an advantage of everyday creativity was linked to a subtle clinical picture (schizotypal signs) in a nonpsychotic sample of schizophrenia offspring.

However, it lacks the confirmation (b) in the nuclear genome model. This hypothesis, although theoretically plausible and fascinating, has not been supported by most epidemiological studies, which show a decreased reproductive fitness of unaffected siblings of patients with schizophrenia. Although recent large-sampled epidemiological studies (Bassett et al., 1996; McGrath et al., 1999; Haukka et al., 2003; Svensson et al., 2007) have consistently shown that the reproductive fitness of unaffected female siblings of patients with schizophrenia is slightly but significantly increased (1.02-1.08), it is not large enough to compensate for the gene loss due to the decreased reproductive fitness of patients (0.2-0.3 in males and 0.4-0.5 in females) and their unaffected male siblings (0.9-1.0) in the nuclear genome model. On the other hand, the latest meta-analysis (Bundy et al., 2011) shows no significant difference between the fertility of parents of patients with schizophrenia and healthy controls, although there is a trend towards parents having more offspring. Therefore, heterozygote advantage seems not to work in the nuclear genome model.

On the other hand, it works in the mitochondrial genome model because mitochondrial DNA (mtDNA) is transmitted to the next generation only through females. Indeed, we can see that this slightly elevated reproductive fitness of the unaffected female siblings, coupled with the less pronounced decreased reproductive fitness of female patients, is sufficient to compensate for the gene loss; when we calculate $-\Delta$, the cross-generational reduction of the frequency of females with a putative pathogenic mtDNA in the general population, using the data in the largest-sampled cohort study to date (Haukka et al., 2003), we have $-\Delta<5.06 \times 10^{-3}$ (Note). This figure implies that the gene loss can be balanced by de novo 
mutation in the mtDNA which occurs at a rate of $8.8 \times 10^{-4} \sim 1.3 \times 10^{-2}$ per locus per generation $\left(4.3 \times 10^{-3}\right.$ on average) (Sigurđardóttir et al., 2000).

\section{Persistence criterion for nuclear susceptibility genes for schizophrenia}

As is shown in the previous section, putative pathogenic genes, if located in the mtDNA, are sustained by mutation-selection balance with heterozygote advantage. On the other hand, if located in the ncDNA, they should be sustained by mutation-selection balance without heterozygote advantage. In this section, we introduce our previous work (Doi et al., 2009), in which we carefully re-examined the necessary conditions for putative nuclear susceptibility genes for schizophrenia and deduced a criterion (persistence criterion, or 'P-criterion') that every nuclear susceptibility gene should fulfill for persistence of the disease, and present its applications to association studies for schizophrenia.

\subsection{Three basic assumptions}

At first we describe our three basic assumptions.

\subsubsection{An ideal human population}

We assume here a random-mating human population with a sufficiently large effective population size at equilibrium, where negative selection pressures on the susceptibility alleles for schizophrenia are predominant and the effect of genetic drift is negligibly small. The prevalence $p$ of schizophrenia in this ideal human population is assumed to be stable across generations by mutation-selection balance. Therefore, the gene frequency in the general population $\left(m_{G}\right)$ is given in terms of the gene frequencies in the affected population $\left(m_{A}\right)$ and in the unaffected population $\left(m_{U}\right)$ :

$$
\left.m_{G}=p m_{A}+(1-p) m_{U}, \text { or } m_{A}-m_{G}=(1-p) d . d \equiv m_{A}-m_{U}\right)
$$

\subsubsection{Mutation-selection balance in each risk locus}

We assume here that the total of the population frequencies of the pathogenic alleles at each risk locus is preserved by mutation-selection balance. Therefore, $-\Delta m_{G}$, the cross-generational reduction of the frequency of a pathogenic allele should not be more than the rate of mutations that produce pathogenic variants at the locus. On the other hand, since mutations at the locus include mutations of two directions that produce pathogenic or non-pathogenic variants, the mutation rate at the locus $(\mu)$ should be greater than the rate of mutations that produce pathogenic variants at the locus.

Thus we have:

$$
\mu>-\Delta m_{G}
$$

\subsubsection{Multifactorial threshold model}

We assume the multifactorial threshold model, in which quantitative traits such as liability to the disease are determined by multiple genetic and non-genetic factors including a 
stochastic and/or an epigenetic effect. Under this assumption, the relative fitness as a quantitative trait in the affected population is determined by multiple factors and approximately follows a gamma distribution with a mean $(1-s)$. ( $s$ is the selection coefficient of schizophrenia; the mean relative fitness in the normal population is 1.)

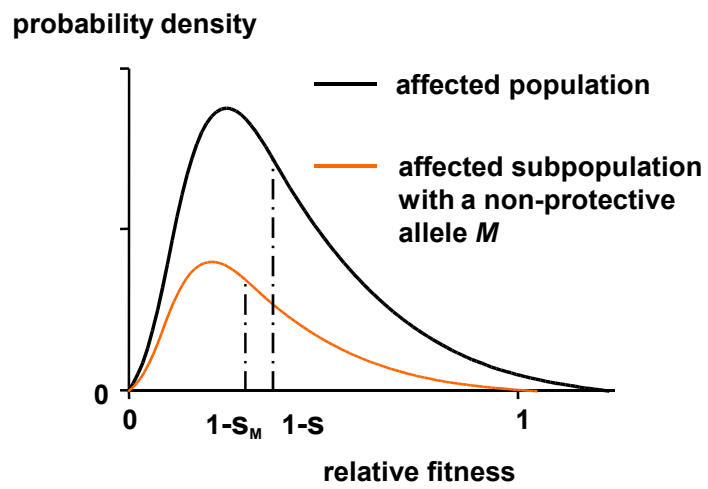

Fig. 2. Distribution curve of the reproductive fitness in the affected population

Distribution curve of the reproductive fitness in the affected subpopulation with a schizophrenia-associated allele $M$ never shifts to the right unless $M$ has a strong protective effect (i.e. an effect of elevating carrier's reproductive fitness by reducing severity of and liability to the disease). Therefore, we can assume that $s_{M}$, the selection coefficient in the affected subpopulation with a schizophrenia-associated allele $\mathrm{M}$, is not smaller than $s$ $\left(s \leq s_{M}<1\right)$ for a susceptibility allele (Fig. 2). The inequality $s>s_{M}$ implies that $M$ is a resistance gene that reduces severity and risk of the disease.

No special assumptions else are required on the allelic structure in each locus, penetrance of each susceptibility gene, and possible interactions among the loci.

\subsection{Deduction of the P-criterion}

Now we proceed to deduce the P-criterion. From the assumptions, $m_{G}^{\prime}$, the population frequency of the schizophrenia-associated allele $\mathrm{M}$ in the next generation, is given by:

$$
m_{G}^{\prime}=\frac{p \cdot m_{A} \cdot\left(1-s_{A}\right)+(1-p) \cdot m_{U} \cdot 1}{p \cdot\left(1-s_{M}\right)+(1-p) \cdot 1}=\frac{m_{G}-s_{M} p m_{A}}{1-s_{M} p} .
$$

Therefore the reduction of the population frequency of the schizophrenia-associated allele $\mathrm{M}$ per generation is:

$$
-\Delta m_{G}=m_{G}-m_{G}^{\prime}=\frac{s_{M} p\left(m_{A}-m_{G}\right)}{1-s_{M} p}=p(1-p) d \cdot \frac{s_{M}}{1-s_{M} p} .
$$


From (2) and (3) we have:

$$
\mu>p(1-p) d \cdot \frac{s_{M}}{1-s_{M} p}
$$

Since $\frac{s_{M}}{1-s_{M} p}$ is monotonically increasing for $s_{M}\left(0<s_{M}<1\right)$ and $s \leq s_{M}<1$ holds for the susceptibility allele $M$, we have:

$$
\mu>p(1-p) d \cdot \frac{s}{1-s p}, \text { or } \frac{(1-s p) \mu}{(1-p) s p}>d
$$

On the other hand, the principle of association studies demands: $0<d$.

Thus we have the criterion for a susceptibility gene:

$$
0<d<v \text {, where } v \text { is defined as } v \equiv \frac{(1-s p) \mu}{(1-p) s p} .
$$

From the observation (5), we can see that $d \geq v$ implies $s>s_{M}$ for any schizophreniaassociated variant $\mathrm{M}$ which is sustained by mutation-selection balance.

\subsection{Parameter estimate for schizophrenia}

Mutation rates on autosomes and the $X$ chromosome almost always fall within the range between $10^{-6}$ and $10^{-4}$ per locus per generation (usually $<10^{-5}$; one generation $=20$ years) (Nachman \& Crowell, 2000) and can be approximated by a linear function of the parental age at least under 30 years for maternal age and under 40 years for paternal age (Risch et al., 1987). Large-sampled cohort studies in Israel, Sweden and Denmark show that the mean age of parents in the general population is $\sim 28$ years for mothers and $\sim 31$ years for fathers; the mean age of both parents is < 29.6 years (Malaspina et al., 2001; El-Saadi et al., 2004). Therefore we assume here:

$$
10^{-6}<\mu<\frac{29.6}{20} \times 10^{-4}=1.48 \times 10^{-4}
$$

According to the epidemiological data by Haukka et al. (2003), the estimated values for $p$ and $s$ are $p=1.29 \times 10^{-2}$ and $s=6.54 \times 10^{-1}$. Therefore, we have $v=1.76 \times 10^{-3}$ for the average mutation rate $\left(1.48 \times 10^{-5}\right), v=1.76 \times 10^{-2}$ for the highest mutation rate $\left(1.48 \times 10^{-4}\right)$, and $v=1.76 \times 10^{-4}$ for a relatively low mutation rate $\left(1.48 \times 10^{-6}\right)$.

\subsection{Implications for association studies of schizophrenia}

We present here some applications of the P-criterion to association studies of schizophrenia. The results suggest that common disease/common variant hypothesis is unlikely to fit schizophrenia and that an enormous sample size is required to detect a nuclear susceptibility gene for schizophrenia. 


\subsubsection{Calculation of an upper bound of the effect size of a putative susceptibility gene of a given frequency}

Using the P-criterion, we can calculate an upper bound of the effect size of a putative susceptibility gene of a given frequency.

Effects size of a susceptibility gene $M$ is expressed by odds ratio defined as

$$
O R=\frac{m_{A}\left(1-m_{U}\right)}{\left(1-m_{A}\right) m_{U}}
$$

which is monotonically increasing for $m_{A}$ and monotonically decreasing for $m_{U}$. Since the criterion demands $m_{U}<m_{A}<m_{U}+v$, we have

$$
\frac{m_{U}\left(1-m_{U}\right)}{\left(1-m_{U}\right) m_{U}}<\mathrm{OR}<\frac{\left(m_{U}+v\right)\left(1-m_{U}\right)}{\left(1-m_{U}-v\right) m_{U}} \text {, or } 1<\mathrm{OR}<1+\frac{v}{m_{U}\left(1-v-m_{U}\right)}
$$

for $0<m_{U}<1-v$.

And since the criterion demands $m_{A}-v<m_{U}$, we have

$$
1<\mathrm{OR}<\frac{m_{A}\left(1-m_{A}+v\right)}{\left(1-m_{A}\right)\left(m_{A}-v\right)}=1+\frac{v}{\left(1-m_{A}\right)\left(m_{A}-v\right)}
$$

for $1-v \leq m_{U}<1$.

Thus, we have an upper bound of the effect size for a given frequency.

From the above we can easily see that the common disease/ common variant hypothesis, which proposes that common alleles at a handful of loci interact to cause a common disease, is unlikely to fit schizophrenia. No common alleles with population frequency between 0.05 and 0.95 can have large effects for schizophrenia: the odds ratio of every common risk allele is less than 1.04 for the average mutation rate, less than 1.58 for the highest mutation rate, and less than 1.004 for a relatively low mutation rate (Table 1).

\subsubsection{Calculation of range of the frequency of a putative susceptibility gene of a given effect size}

By solving the inequality (7) or (8), we can estimate the range of gene frequency for a given effect size. Thus, we can see that susceptibility genes of the average mutation rate and a moderate effect that meet the criterion are limited to 'very rare variants' or 'very common variants'. For example, suppose $\mu=1.48 \times 10^{-5}$ and $O R=5.0$, then we have: $v=1.76 \times 10^{-2}$ and

$$
4<\frac{v}{m_{U}\left(1-v-m_{U}\right)}
$$

Solving this inequality, we get either $0<m_{U}<0.00044$ (that is, $0<m_{A}<m_{U}+0.00176<0.0022$ ) or $m_{U}>0.9977$. 


\begin{tabular}{|c|c|c|c|}
\hline$m_{U}$ & $\mu=1.48 \times 10^{-6}$ & $\mu=1.48 \times 10^{-5}$ & $\mu=1.48 \times 10^{-4}$ \\
\hline 0.01 & $<1.02$ & $<1.18$ & $<2.81$ \\
\hline 0.02 & $<1.009$ & $<1.09$ & $<1.92$ \\
\hline 0.05 & $<1.004$ & $<1.04$ & $<1.38$ \\
\hline 0.1 & $<1.002$ & $<1.02$ & $<1.20$ \\
\hline 0.3 & $<1.0009$ & $<1.009$ & $<1.08$ \\
\hline 0.5 & $<1.0008$ & $<1.008$ & $<1.09$ \\
\hline 0.7 & $<1.0009$ & $<1.009$ & $<1.24$ \\
\hline 0.9 & $<1.002$ & $<1.02$ & $<1.58$ \\
\hline 0.95 & $<1.004$ & $<1.04$ & $<8.49$ \\
\hline 0.98 & $<1.009$ & $<1.10$ & $<$ \\
\hline
\end{tabular}

Table 1. Upper bounds of odds ratio for given allele frequencies in the unaffected population

\subsubsection{Calculation of the required sample size and the power of an association study}

Using the P-criterion we can calculate a lower bound of sample size required in an association study of a given power as well as an upper bound of the power of an association study of a given sample size.

Concerning the required sample size $2 N$ ( $N$ case-control pairs) and the power $1-\beta$ of an association study, we have the well-established formulae (Ohashi \& Tokunaga, 2002):

$$
N \cong \frac{1}{2}\left(\frac{z^{*}{ }_{\alpha} \sqrt{2 x(1-x)}+z_{\beta} \gamma}{d}\right)^{2},
$$

and

$$
1-\beta \cong \Phi\left(\frac{\sqrt{2 N} d-z^{*}{ }_{\alpha} \sqrt{2 x(1-x)}}{\gamma}\right) .
$$

Here, $\Phi, z^{*}{ }_{\alpha}$, and $z_{\beta}$ denote the cumulative distribution function of the standard normal curve, the two sided $a$ point ( $a$ : a significant level) and the upper $\beta$ point of the standard normal curve, and $x$ (population frequency of the allele) and $\gamma^{2}$ are defined as follows.

$$
x \equiv \frac{1}{2}\left(m_{A}+m_{U}\right) \quad \gamma^{2} \equiv m_{A}\left(1-m_{A}\right)+m_{U}\left(1-m_{U}\right)=2 x(1-x)-\frac{1}{2} d^{2}
$$

For the average mutation rate $\mu=1.48 \times 10^{-5}$, we have $v=1.76 \times 10^{-3}$. Suppose $0.0005<x<0.9995$, then we have $2 x(1-x)>0.9995 \times 10^{-3}$. From the P-criterion, we have:

$$
\frac{1}{2} d^{2}<\frac{1}{2} v^{2}<1.6 \times 10^{-6}<2 x(1-x) \times 0.002 .
$$

Therefore, we have the following approximation with an error smaller than $0.2 \%$ : 


$$
\gamma^{2}=2 x(1-x)-\frac{1}{2} d^{2} \cong 2 x(1-x), \text { or } \gamma \cong \sqrt{2 x(1-x)} .
$$

Thus, we have:

$$
\begin{aligned}
& N \cong \frac{1}{2}\left(\frac{z^{*}{ }_{\alpha} \sqrt{2 x(1-x)}+z_{\beta} \gamma}{d}\right)^{2} \cong\left(\frac{z^{*}{ }_{\alpha}+z_{\beta}}{d}\right)^{2} x(1-x)>\left(\frac{z^{*}{ }_{\alpha}+z_{\beta}}{v}\right)^{2} x(1-x) \\
& 1-\beta \cong \Phi\left(\frac{\sqrt{2 N} d-z^{*}{ }_{\alpha} \sqrt{2 x(1-x)}}{\gamma}\right) \cong \Phi\left(\sqrt{\frac{N}{x(1-x)}} d-z^{*}{ }_{\alpha}\right)<\Phi\left(\sqrt{\frac{N}{x(1-x)}} v-z^{*}{ }_{\alpha}\right)
\end{aligned}
$$

Let us calculate the required sample size in a genome-wide association study $\left(\alpha=2.5 \times 10^{-7}, 1-\beta=0.95\right)$. Since we have $z^{*}{ }_{0.00000025}+z_{0.05}=6.79$ ，

$$
N>\left(\frac{z^{*}{ }_{\alpha}+z_{\beta}}{v}\right)^{2} x(1-x)=\left(\frac{6.79}{1.76 \times 10^{-3}}\right)^{2} x(1-x)=3.72 \times 10^{6}
$$

for $x=0.5$. Therefore, more than 3.7 million case-control pairs are required in a genomewide association study with a power 0.95 to detect a susceptibility variant of the average mutation rate and a population frequency between 0.0005 and 0.9995 .

Similarly we can see that more than 37,000 case-control pairs are required in a genome-wide association study with a power 0.95 to detect a susceptibility variant of the highest mutation rate $\left(\mu=1.48 \times 10^{-4}\right)$ and a population frequency between 0.005 and 0.995 .

Finally, let us consider the case with a relatively low mutation rate $\mu=1.48 \times 10^{-6}$, which corresponds to $v=1.76 \times 10^{-4}$. In this case, more than 370 million case-control pairs are required in a genome-wide association study with a power 0.95 to detect a susceptibility variant of a population frequency between 0.000005 and 0.999995 . Therefore it would take more than several hundred years to gather the required number of samples even if all of the affected individuals in the world were to be recruited to the study.

\section{Mitochondrial DNA (mtDNA) hypothesis of schizophrenia}

In this final section, we discuss on the nature of those schizophrenia-associated genes that do not meet the P-criterion, suggesting that these genes should be resistance genes that reduce the morbid risk and severity of the disease. We show that the results of association studies to date is compatible with the mitochondrial genome model but not with the nuclear genome model and propose a new hypothesis which assumes that the risk loci are in the mtDNA. We present eight major predictions of this hypothesis, and discuss that these predictions seem to accord with the other epidemiological findings and the results of the genetic and the pathophysiological studies to date.

\subsection{Nature of schizophrenia-associated genes that do not meet the P-criterion}

Now, let us consider the nature of those schizophrenia-associated genes that do not meet the persistence criterion. The inequality $d \geq v$ implies $s_{M}<s$, where $s_{M}$ and $s$ denote the selection 
coefficient in the affected subpopulation with an allele $\mathrm{M}$ and in the affected population respectively. Therefore, such genes, if sustained by mutation-selection balance, cannot be susceptibility genes but resistance genes that reduce severity and risk of the disease (see 4.2). If they were not resistance genes, their frequencies in the affected population must have been reduced to the same level in the unaffected population.

\subsection{The results of association studies to date accord with the mitochondrial genome model but not with the nuclear genome model}

Since a resistance gene in the nuclear genome model cannot be associated with the disease unless it is linked with a susceptibility gene, resistance genes in the nuclear model should be located in the vicinity of susceptibility genes, which disagrees with the results of association studies to date.

For example, on the chromosome 1, all of the schizophrenia-associated genes that could meet the criterion (RGS4, PLXNA2, DISC1) are located on 1q, while four resistance genes (MHTFR, GRIK3, PDE4B, GSTM1) are on 1p (Table 2). Fifteen resistance genes are located on $2 q, 5 q, 7 q, 10 q, 11 p, 12 p, 12 q, 13 p, 13 q, 16 p, 17 p$, and 19q, where no schizophreniaassociated variants that could meet the criterion are located (data: not shown). Therefore, the results of association studies to date argue against the nuclear genome model.

A possible interpretation which accords with the nuclear genome model might be that many nuclear susceptibility genes of less than the highest mutation rates have not been detected by association studies to date due to lack of power. In this case, however, an enormous sample size (more than 3.7 370 million case-control pairs) would be required to identify them as was mentioned above. In other words, such an enormous sample size is required to prove the nuclear genome model.

On the other hand, every resistance gene on any chromosome can be associated with schizophrenia in the mitochondrial genome model; since mtDNA is transmitted only via females and there is no link between the nuclear genome and the mitochondrial genome, every nuclear genome which interacts with a pathogenic mitochondrial genome to alter severity and risk of the disease is subject to natural selections in the predisposed maternal lineage that succeeds to a same pathogenic mitochondrial genome. Therefore, every resistance gene for schizophrenia in the mitochondrial genome model is to be subject to a positive selection in the predisposed maternal lineage, thereby associating with schizophrenia.

Thus, the mitochondrial genome model is compatible with the results of the association studies to date.

It should be noted that in the mitochondrial genome model every facilitating gene (a gene that increases the severity and morbid risk in the predisposed population) on any chromosome may diminish in the predisposed matrilineal pedigrees by negative selection, thereby negatively associating with the disease.

Schizophrenia-associated variants listed in the top 45 in the SZGene Database (the version of $10^{\text {th }}$ December, 2010) were selected. Based on the genotype distributions in meta-analyses, allele frequencies and the case-control differences were calculated. 4 variants at the 3 loci (RGS4, PLXNA2, DISC1) could meet the criterion under the assumption that the mutation 
rates at those loci are near the upper limit in the autosomes. All of them are located on $1 \mathrm{q}$, while 4 resistance genes (MHTFR, GRIK3, PDE4B, GSTM1) are on 1p. * schizophreniaassociated alleles; variants that could meet the criterion are shown in bold characters

\begin{tabular}{|c|c|c|c|c|c|c|}
\hline $\begin{array}{c}\text { Genes and } \\
\text { SNPs }\end{array}$ & Location & $\begin{array}{c}\text { Allele } \\
\text { (minor/major) }\end{array}$ & $m_{A}$ & $m_{U}$ & OR & $d$ \\
\hline MHTFR & $1 \mathrm{p} 36.22$ & & & & & \\
\hline rs1801133 & & $\mathrm{T}^{*} / \mathrm{C}$ & 0.3532 & 0.3211 & 1.15 & 0.032 \\
\hline GRIK3 & $1 \mathrm{p} 34.3$ & & & & & \\
\hline rs6691840 & & $\mathrm{G}^{*} / \mathrm{T}$ & 0.2600 & 0.2226 & 1.25 & 0.037 \\
\hline PDE4B & $1 \mathrm{p} 31.3$ & & & & & \\
\hline rs910694 & & $\mathrm{C} / \mathrm{T}^{*}$ & 0.5780 & 0.5477 & 1.30 & 0.030 \\
\hline GSTM1 & $1 \mathrm{p} 13.3$ & & & & & \\
\hline GSTM1*0 & & ins-allele/del- & 0.7546 & 0.7140 & 1.35 & 0.041 \\
\hline RGS4 & $\mathbf{1 q 2 3 . 3}$ & & & & & \\
\hline rs2661319 & & $\mathrm{A} / \mathrm{G}^{*}$ & 0.4920 & 0.4744 & $\mathbf{1 . 0 8}$ & $\mathbf{0 . 0 1 7 6}$ \\
\hline IL10 & $1 \mathrm{q} 32.1$ & & & & & \\
\hline rs1800896 & & $\mathrm{G}^{*} / \mathrm{A}$ & 0.3056 & 0.2657 & 1.42 & 0.040 \\
\hline PLXNA2 & $\mathbf{1 q 3 2 . 2}$ & $\mathrm{A} / \mathrm{G}$ & & & & \\
\hline rs841865 & & $\mathrm{A} / \mathrm{G}^{*}$ & 0.8434 & 0.8001 & 1.32 & 0.043 \\
\hline rs1327175 & & $\mathrm{G} / \mathbf{C}^{*}$ & 0.92840 & 0.91243 & 1.32 & $\mathbf{0 . 0 1 6}$ \\
\hline DISC1 & $\mathbf{1 q 4 2 . 3}$ & & & & & \\
\hline rs3737597 & & $\mathbf{A}^{*} / \mathrm{G}^{*}$ & 0.03069 & 0.01735 & 1.80 & $\mathbf{0 . 0 1 3}$ \\
\hline rs999710 & & $\mathbf{A}^{*} / \mathrm{G}^{*}$ & 0.3989 & 0.3819 & 1.07 & $\mathbf{0 . 0 1 7 0}$ \\
\hline
\end{tabular}

Table 2. Schizophrenia-associated genes on the chromosome 1 that could meet the criterion

\subsection{The mtDNA hypothesis for schizophrenia and its predictions}

Thus we propose here a new hypothesis which insists that the risk loci for schizophrenia are in the mtDNA.

Mitochondria are involved in a variety of major cellular events such as oxidative phosphorylation, free radical production and $\mathrm{Ca}^{2+}$ buffering, and play an active role in apoptosis. They possess two classes of antioxidant defense system (non-enzymatic and enzymatic), and structurally and functionally intact mitochondria serve as a net sink rather than a net source of reactive oxygen species (ROS) (Andreyev et al., 2005). ROS-defenses are severely undermined in structurally compromised mitochondria (Andreyev et al., 2005). Thus, mitochondrial dysfunction, presumably through imbalance of ROS production and removal (Andreyev et al., 2005), raises ROS emission (Esposito et al., 1999; Senoo-Matsuda et al., 2001) and causes intracellular oxidative stress.

Because abnormal mtDNA may cause mitochondrial dysfunction, the hypothesis predicts: (1) enhanced oxidative stress and disturbed energy metabolism in predisposed individuals, which may cause various pathogenic alterations such as genomic instability, aberrations in neurodevelopment, and the brain dysfunction. Furthermore, because mtDNA can be transmitted only through females and there is no link between the nuclear genome and the 
mitochondrial genome, the mtDNA hypothesis predicts: (2) a higher maternal transmission of schizophrenia, and (3) positive associations between resistance genes and schizophrenia as well as negative associations between facilitating genes and schizophrenia (see 5.2). These predictions seem to be consistent with other major epidemiological findings and the results of the genetic and the pathophysiological studies to date.

\subsubsection{Mitochondrial dysfunction and enhanced oxidative stress in affected individuals}

The hypothesis predicts that patients with schizophrenia show mitochondrial dysfunction and enhanced oxidative stress.

Indeed, in the past decade, mitochondrial dysfunction and oxidative stress in schizophrenia has been suggested by several independent lines of evidence (for review, see Marchbanks et al., 1995; Ben-Shaffer, 2002; Wood et al., 2009); those include mitochondrial hypoplasia, disturbed oxidative phosphorylation, and altered mitochondrial-related gene expression in several cell lines.

The pioneering works in this field may be noteworthy (Utena \& Niwa, 1992). As early as 1950, Hayashi, in a longitudinal study on glucose metabolites in blood sampled from the superior bulb of the internal jugular vein of schizophrenics, observed a decreased carbonic dioxide production in the brain and a higher level of lactate and glutathione, the brain's dominant free radical scavenger, in patients in an acute exacerbation of the illness. Utena and Ezoe (1951) reported a decreased glucose consumption in vitro in cortical brain tissues sampled from patients with schizophrenia who underwent prefrontal leukotomy. Takahashi (1953) confirmed this finding and emphasized the necessity of further investigations on oxidative phosphorylation in the brain tissue of schizophrenics. In line with those findings was the report by Stabenau et al. (1969), who observed, in a biochemical study of discordant monozygotic twin pairs, that lactate production and the lactate-pyruvate ratio were higher in the affected twins than the unaffected cotwins. More recently, Prabakaran et al. (2004), in a large-scale functional genomics study, suggested a state of intermittent or chronic hypoxic stress and mitochondrial dysfunction in the brain of patients with schizophrenia.

\subsubsection{The mode of transmission}

The hypothesis predicts a higher maternal transmission of schizophrenia. Although there has been no convincing evidence for maternal transmission of schizophrenia, several reports suggest a higher maternal transmission of schizophrenia (Shimizu et al., 1987; Goldstein et al., 1990; Valero et al., 1998; Li et al., 2007).

Some researchers have proposed the hypothesis that schizophrenia is associated with de novo mutations arising in paternal germ cells (Malaspina et al., 2001; Zammit et al., 2003; Byrne et al., 2003; El-Saadi et al., 2004; Sipos et al., 2004). It is based on the observation ('paternal age effect') that the risk of schizophrenia in the offspring seems to increase as the paternal age advances from 20 years to over 50 years.

However, the difference in the mean ages of fathers between affected and unaffected individuals are not very large (< 1.7 years) (Malaspina et al., 2001; El-Saadi et al., 2004). Furthermore, the risk of schizophrenia was also increased in the offspring of younger men 
(<21 years) (Malaspina et al., 2001; El-Saadi et al., 2004; Sipos et al., 2004) as well as in the offspring of younger women (<20 years) (El-Saadi et al., 2004). Therefore, major roles of paternally derived mutations in schizophrenia seem to remain unsubstantiated.

Indeed, no available data can exclude the possibility that the 'paternal age effect' has a 'maternal origin'; while women in many countries today may be usually supposed to bear children after the age of 20 years and not to marry much older men or too young men unless the men have special socio-economic benefits, a certain proportion of predisposed women might behave differently.

It should be noted that in the famous twin study by Gottesman and Bertelsen (1989) which included almost equal number of male and female monozygotic twins, most schizophrenic twins whose offspring are affected are females (12 out of 14), implying that the transmission was mainly via females $\left(p={ }_{14} C_{12} \times 0.5^{14}+{ }_{14} C_{13} \times 0.5^{14}+{ }_{14} C_{14} \times 0.5^{14}<0.007\right)$. While this gender effect might be due to non-genetic factors such as stronger psychological interactions between mother and child, we must also consider the possibility that it is due to the closer genetic relationship between mother and child, i.e. the mtDNA.

\subsubsection{Sex difference and a protective effect of estrogen in schizophrenia}

The hypothesis predicts that endogenous antioxidants exhibit a protective effect against schizophrenia, and may give a plausible explanation for sex difference of the disease.

A consistent and specific finding for schizophrenia is that the age at onset is significantly lower in males than in females (Jablensky, 1995; Kulkarni \& Fink, 2000); schizophrenia starts earlier on average in males and reaches its peak between 15 and 25 years of age, whereas in females it occurs almost between 20 and 30 years of age and shows a less steep curve after that age. It also appears that women are vulnerable to relapses or first episode of schizophrenia in the perimenoposal period (the second peak of onset for females) (Kulkarni \& Fink, 2000), when estrogen production diminishes. A close association between premenstrual or menstruation phase and exacerbation of the illness in females has been well documented (Kulkarni \& Fink, 2000). In addition, less negative symptoms, less brain morphological changes, and better response to neuroleptic medication are relatively consistent finding in female patients with schizophrenia (Jablensky, 1995; Goldstein \& Lewine, 2000).

These observations lead to the concept that estrogen protects predisposed females (Kulkarni \& Fink, 2000), which seems to accord with the hypothesis; estrogen has been shown to have antioxidant activity due to its intrinsic antioxidant structure that lies in the phenolic moiety of the steroidal compound (Behl, 2002), to increase antioxidant enzyme activities (Strehlow et al., 2003; Pajović et al., 2003), and to have neuroprotective effect against oxidative stress (Behl, 2002; Brann et al., 2007). Furthermore, mitochondrion has estrogen binding sites (Monje \& Boland, 2001; Chen et al., 2004) and estrogen increases mitochondrial efficiency and reduces intracellular oxidative stress (Stirone et al, 2005).

\subsubsection{Low comorbidity between schizophrenia and rheumatoid arthritis}

The hypothesis predicts that diseases predisposed by facilitating genes, if present, would be negatively associated with schizophrenia. Rheumatoid arthritis could be one of such candidates. 
A role of oxidative stress in the pathogenesis of rheumatoid arthritis has been suggested by several lines of evidence (for review, see Hitchon et al, 2004). In addition, it has been shown that chronic oxidative stress in the synovial $\mathrm{T}$ lymphocytes is not secondary to exposure to environmental free radicals but originates from intracellularly produced reactive oxygen species (Remans et al, 2005). Therefore, a presumptive susceptibility gene for rheumatoid arthritis, which may cause intracellular oxidative stress in several cell lines, could be a facilitating gene for schizophrenia in this model and is likely to be subject to a negative selection in the predisposed matrilineal pedigrees.

Indeed, robust evidence shows a negative association between schizophrenia and rheumatoid arthritis while the exact mechanism is still unknown (Vinogradov et al., 1991; Jablensky, 1995; Rubinstein, 1997; Oken 1999). According to the nuclear genome model, several hypotheses have been proposed such that pathogenic genes for schizophrenia may be protective genes for rheumatoid arthritis and vice versa.

Thus the mitochondrial genome model may offer a new explanation for the low comorbidity between schizophrenia and rheumatoid arthritis and the additional prediction: most of patients with both of the diseases would be females because the survival rate of males in early life stage must be remarkably reduced due to lack of the antioxidant defense by estrogen, and show more negative symptoms, poorer response to neuroleptic medication, and/or more morphological changes in the brain.

\subsubsection{Prenatal risk factors for schizophrenia}

The hypothesis predicts that early-life exposure to environments which induce strong oxidative stress can increase the risk of later development of schizophrenia in the predisposed population.

Indeed, prenatal environmental factors such as severe nutritional deficiency (Susser, et al., 1996), exposure to increased homocysteine (Brown et al., 2007) or lead (Opler \& Susser, 2005), and infection of influenza virus (Limosin et al., 2003; Brown et al., 2004; Opler \& Susser, 2005) and Toxoplasma gondii (Brown et al., 2005) have been suggested to increase the risk for schizophrenia. More recently, it has been suggested that central nervous system infections of cytomegalovirus or mumps virus in childhood may also increase the risk for schizophrenia (Dalman et al., 2008). All of these factors have been shown to affect mitochondria, inducing strong intracellular oxidative stress and/or apoptosis (Akaike et al., 1990; Edlund et al., 1994; Speir et al., 1998; He et al., 2003; Berger et al., 2004; Zaki et al., 2005; Gupta et al., 2004; Kruman et al., 2006; Wang et al., 2006; Poncet et al., 2006; Chang et al., 2007; Nishikawa et al., 2007).

\subsubsection{Increased obstetric complications in the birth of patients with schizophrenia}

It has been suggested that mitochondrial dysfunction may be involved in the etiology of preeclampsia (Shanklin et al., 1990; Barton et al., 1991; Furui et al., 1994). In addition, a high incidence of preeclampsia, eclampsia, and stillborn infants has been observed in a family with a known mitochondrial disorder (Torbergsen et al. 1989). Folgero et al. (1996) demonstrated two separate mtDNA point mutations in two families having a high incidence of preeclampsia and eclampsia. 
Therefore, the hypothesis predicts that the risk of preeclampsia, eclampsia, or stillbirth may be increased in the birth of patients with schizophrenia as well as in the pregnancies of women with schizophrenia. Indeed, an excess of stillbirths and neonatal deaths among women with schizophrenia has been reported by several investigators (Sobel, 1961; Rieder et al., 1975; Modrzewska, 1980; Webb et al., 2005).

Furthermore, there has been a body of evidence for an increased risk of obstetric complications in the birth of patients with schizophrenia (Dalman et al., 1999; Cannon et al., 2002). A meta-analysis of population-based data (Cannon et al., 2002) found significant estimates for three main categories of obstetric complications: (1) complications of pregnancies, (2) abnormal fetal growth and development, and (3) complications in delivery. Among all, preeclampsia was the strongest individual risk factor detected in the largest single population-based cohort study to date (Dalman et al., 1999).

Although obstetrical events in schizophrenia are often considered as having a direct causative effect, none of the available data can refute the hypothesis that they are merely markers of some other causal process (Rapoport et al., 2005), such as mitochondrial dysfunction which is implicated in this hypothesis.

\subsubsection{An apparent signature of positive selection in schizophrenia-associated genes}

Since the positive selection of the schizophrenia-associated alleles mentioned above occurs only in the predisposed matrilineal pedigrees, a ubiquitous subpopulation in humans, frequencies of those alleles may not be so high in the general population as if the selection had occurred recently in the general population.

Thus, the hypothesis predicts that every schizophrenia-associated nuclear gene shows an apparent signature as if it had been subject to a positive selection in the recent evolutionary history of humans. Recent two reports (Lo et al, 2007; Crespi et al., 2007) seem to be in line with this prediction.

On the other hand, the nuclear genome model predicts that every schizophrenia-associated nuclear gene shows an apparent signature of negative selection due to the strong negative selection pressure.

\subsubsection{Genomic instability}

It is generally thought that a major cause of DNA damage that leads to mutations is reactive oxygen species, which are generated as a normal part of oxygen metabolism but are also produced by ionising radiation, metabolism of exogenous compounds (Hussain et al., 2003; Finkel, 2003). It has been shown that endogenous mitochondrial oxidative stress can induce many types of DNA damage including double strand breaks, end-to-end fusions, base and sugar modifications, DNA-protein cross-links, and gross chromosomal rearrangements (Ragu et al., 2007; Samper et al., 2003).

Therefore, the hypothesis predicts that the enhanced oxidative stress may cause genomic instability during meiosis and/or early phase of ontogeny, producing increased rates of random point mutations and/or structural variants of the nuclear genome in the 
predisposed population. In addition, genomic instability may be more pronounced in males due to lack of antioxidant protection by estrogen.

There have been numerous reports of associations between schizophrenia and chromosomal abnormalities including fragile sites, reciprocal translocations, inversions, insertions, deletions, disomy and trisomy in many autosomes, and sex chromosome aneuploidies (Macintyre et al, 2003). However, with an exception of 22q11 deletion, none of these have been consistently replicated, and with another exception of $(1,11)$ (q42;q14.3) balanced translocation, none provides convincing evidence for the location of a 'susceptibility' gene (Kirov et al., 2005).

A popular explanation in the nuclear genome model may be that most of these structural variants are coincidental findings of no clinical significance. Alternatively, those alterations may indicate genomic instability in schizophrenia. An increased risk of schizophrenia in individuals with 22q11 deletion (Pulver et al., 1994; Murphy et al., 1999) might be due to haplodeficiency of presumptive resistance genes of gain-offunction type and/or presumptive facilitating genes of loss-of-function type aggregated on $22 \mathrm{q} 11$.

More recently, it has been reported that rare structural variants such as microdeletions or microduplications of sizes ranging from $100 \mathrm{~kb}$ to $15 \mathrm{MB}$ throughout the genome are more frequent among individuals with schizophrenia than unaffected individuals (Walsh et al., 2008). While many of those structural variants duplicate or delete genes in neurodevelopmental pathways, one third of those do not disrupt genes, leaving their role in causation of the disease unwarranted. Another recent report (Xu et al., 2008) has shown that de novo copy number mutations are increased in sporadic schizophrenia. However, the cytobands of those copy number mutations are diverse among the affected individuals and their roles in the pathogenesis still remain unclear. Therefore, no available data can refute the possibility that those structural variants and copy number mutations are not the causes of schizophrenia but the results of the genomic instability in schizophrenia predicted by our hypothesis.

Indeed, direct measure of the de novo mutation rates shows an increased mutation rate in schizophrenia (Awadalla et al., 2010), and genomic and epigenomic instability has been suggested in schizophrenia (Smith et al., 2010). Furthermore, it has been shown that blood cells from patients with schizophrenia present a higher rate of folate-sensitive fragile sites, and that male patients exhibit twice as many fragile sites as females while there are no age effects (Demirhan et al., 2006). This sex difference may indicate that increased fragile sites expression (genomic instability) is the results of enhanced oxidative stress in patients with schizophrenia.

\section{Conclusion}

Genetic research of schizophrenia based on the nuclear genome model has been one of the most active areas in psychiatry for the past two decades. Although this effort is ongoing, results of association studies have been inconsistent and the situation of molecular genetics of schizophrenia today has become much confused just contrary to our expectation. The consistent major epidemiological findings of schizophrenia, coupled with the results of association studies to date, argue against the nuclear genome model for schizophrenia. 
Rather, they seem to argue in favor of the mitochondrial genome model, suggesting a necessity of paradigm shift from the nuclear genome model to the mitochondrial genome model in genetic research of schizophrenia in the coming years.

\section{Note: Cross-generational reduction of females with pathogenic genes in the mitochondrial genome model}

At first we define several notations. $N_{1}$ : the number of normal females in the first generation; $N_{2}$ : number of female offspring of normal females; $S_{1}$ : the number of unaffected female siblings of patients in the first generation; $S_{2}$ : the number of female offspring of unaffected female siblings of patients; $P_{1}$ : the number of female patients; $P_{2}$ : the number of female offspring of female patients; $r(0<r<1)$ : the proportion of gene carriers in normal females in the first generation. Then the number of female gene carriers in the first generation is $\left(r N_{1}+S_{1}+P_{1}\right)$ and the frequency of female gene carriers in the first generation is given by:

$$
f_{1}=\frac{r N_{1}+S_{1}+P_{1}}{N_{1}+S_{1}+P_{1}}=r+\frac{S_{1}+P_{1}}{N_{1}+S_{1}+P_{1}} \cdot(1-r) .
$$

And the frequency of female gene carriers in the second generation is given by:

$$
f_{2}=\frac{r N_{2}+S_{2}+P_{2}}{N_{2}+S_{2}+P_{2}}=r+\frac{S_{2}+P_{2}}{N_{2}+S_{2}+P_{2}} \cdot(1-r) \text {. }
$$

Thus we have (Table 3):

$$
-\Delta=f_{1}-f_{2}=\left(\frac{S_{1}+P_{1}}{N_{1}+S_{1}+P_{1}}-\frac{S_{2}+P_{2}}{N_{2}+S_{2}+P_{2}}\right) \times(1-r)<5.06 \times 10^{-3} .
$$

\begin{tabular}{|c|c|c|c|c|c|}
\hline & $N$ & $S$ & $P$ & Total & $(S+P) /$ Total \\
\hline \# of females & 410,093 & 11,873 & 4,784 & 426,750 & 0.03903 \\
\hline $\begin{array}{c}\text { \# of female } \\
\text { children }\end{array}$ & 366,460 & 10,969 & 1,917 & 379,346 & 0.03397 \\
\hline$-\Delta$ & & & & & $0.00506 \times(1-r)<5.06 \times 10^{-3}$ \\
\hline
\end{tabular}

Table 3. Epidemiological data by Haukka et al. (2003)

In this largest-sampled cohort study to date, Haukka et al. comprised all births in Finland during 1950-1959 (N=870,093) and followed up through the National Hospital Discharge Register for Hospitalizations between 1969 and 1992. N: normal females; S: unaffected female siblings of patients; $P$ : female patients with schizophrenia

\section{References}

Akaike, T., Ando, M., Oda, T., Doi, T., Ijiri, S., Araki, S. \& Maeda, H. (1990). Dependence on $\mathrm{O}_{2}$ - generation by xanthine oxidase of pathogenesis of influenza infection in mice. $J$ Clin Invest, Vol. 85, (Mar 1990), pp. 739-745, ISSN 0021-9738 
Allen, N.C., Bagades, S., McQueen, M.B., Ioannidis, J.P.A., Kavvoura, F.K., Khoury, M.J., Tanzi, R.E. \& Bertram, L. (2008). Systematic Meta-Analyses and Field Synopsis of Genetic Association Studies in Schizophrenia: The SZGene Database. Nat Genet, Vol. 40, No. 7, (July 2008), pp. 827-834, ISSN 1061-4036 http://www.schizophreniaforum.org/res/szgene/default.asp

Andreyev, A.Y., Kushnareva, Y.E. \& Starkov, A.A. (2005). Mitochondrial metabolism of reactive oxygen species. Biocemistry (Moscow), Vol. 70, No. 2, (Feb 2005), pp. 200214, ISSN 0006-2979

Awadalla, P., Gauthier, .J, Myers, R.A., Casals, F., Hamdan, F.F., Griffing, A.R., Côté, M., Henrion, E., Spiegelman, D., Tarabeux, J., Piton, A., Yang, Y., Boyko, A., Bustamante, C., Xiong, L., Rapoport, J.L., Addington, A.M., DeLisi, J.L.E., Krebs, MO., Joober, R., Millet, B., Fombonne, É., Mottron, L., Zilversmit, M., Keebler, J., Daoud, H., Marineau, C., Roy-Gagnon, M-H., Dubé, M-P., Eyre-Walker, A., Drapeau, P., Stone, E.A., Lafrenière, R.G., Rouleau, G.A. (2010). Direct measure of the de novo mutation rate in autism and schizophrenia cohorts. Am J Hum Genet Vol. 87, No. 3, (Sep 2010), pp.316-324, ISSN 0002-9297

Barton, J.R., Hiett, A.K., O'Connor, W.M., Nissen, S.E. \& Greene, J.W. (1991). Endomyocardial ultrastructural findings in preeclampsia. Am J Obstet Gynecol, Vol. 165, No. 2, (Aug 1991), pp. 389-391, ISSN 0002-9378

Bassett, A.S., Bury, A., Hodgkinson, K.A. \& Honer, W.G. (1996). Reproductive fitness in familial schizophrenia. Schizophr Res, Vol. 21, No. 3, (Sep 1996), pp. 151-160, ISSN 0920-9964

Behl, C. (2002). Oestrogen as a neuroprotective hormones. Nat Rev Neurosci, Vol. 3, No. 6 , (Jun 2002),pp. 433-442, ISSN 1471-003X

Ben-Shachar, D. (2002). Mitochondrial dysfunction in schizophrenia: a possible linkage to dopamine. J Neurochemistry, Vol. 83, No. 6, (Dec 2002), pp. 1241-1251, ISSN 14714159

Berger, M.M., Jia, X.Y., Legay, V., Aymard, M., Tilles, J.G. \& Lina, B. (2004). Nutrition- and virus-induced stress repress the expression of manganese superoxide dismutase in vitro. Exp Biol Med, Vol. 229, No. 8, (Sep 2004), pp. 843-849, ISSN 1535-3702

Böök, J.A. (1953). A genetic and neuropsychiatric investigation of a North-Swedish population. Acta Genet et Stat Med, Vo. 4, No. 1, (Jan 1953), pp. 1-100, ISSN 05767440

Brann, D.W., Dhandapani, K., Wakade, C., Mahesh, V.B. \& Khan, M. (2007). Neurotrophic and neuroprotective actions of estrogen: basic mechanism and clinical implications. Steroids, Vol. 72, No. 5, (May 2007), pp. 381-405, ISSN 0039-128X

Brown, A.S., Begg, M.D., Gravenstein, S., Schaefer, C.A., Wyatt, R.J., Bresnahan, M., Babulas, V.P. \& Susser, E.S. (2004). Serologic evidence of prenatal influenza in the etiology of schizophrenia. Arch Gen Psychiatry, Vol. 61, No. 8, (Aug 2002), pp. 774-780, ISSN 0003-990X

Brown, A.S., Shaefer, C.A., Quesenberry, Jr. C.P., Liu, L., Babulas, V.P. \& Susser, E. (2005). Maternal exposure to toxoplasmosis and risk of schizophrenia in adult offspring. Am J Psychiatry, Vol. 162, No. 4, (Apr 2005), pp. 767-773, ISSN 0002-953X

Brown, A.S., Bottiglieri, T., Shaefer, C.A. , Quesenberry, Jr. C.P., Liu, L. Bresnahan, M. \& Susser, E.S. (2007). Elevated prenatal homocysteine levels as a risk factor for schizophrenia. Arch Gen Psychiatry, Vol. 64, No. 1, (Jan 2007), pp. 31-39, ISSN 0003990X 
Brüne, M. (2004). Schizophrenia - an evolutionary enigma? Neurosci Biobehav Rev, Vol. 28, No. 1, (Mar 2004), pp. 41-53, ISSN 0149-7634

Bundy, H., Stahl, D. \& McCabe, J.H. (2011). A systemic review and meta-analysis of the fertility of patients with schizophrenia and their unaffected relatives. Acta Psychiatr Scand, Vol. 123, No. 2, (Feb 2011), pp. 98-106, ISSN 1600-0447

Byrne, M., Agerbo, E., Ewald, H., Eaton, W.W. \& Mortensen, P.B. (2003). Parental age risk of schizophrenia. A case-control study. Arch Gen Psychiatry, Vol. 60, No. 7, (Jul 2003), pp. 673-678, ISSN 0003-990X

Cannon, T.D., Kaprio, J., Lönnqvist, .J, Huttunen, M. \& Koskenvuo, M. (1998). The genetic epidemiology of schizophrenia in a Finnish twin cohort. A population-based modeling study. Arch Gen Psychiatry, Vol. 55, No. 1, (Jan 1998), pp. 67-74, ISSN 0003-990X

Cannon, M., Jones, P.B. \& Murray, R.M. (2002).Obstetric complications and schizophrenia: historical and meta-analytic review. Am J Psychiatry, Vol. 159, No. 7, (July 2002), pp. 1080-1092, ISSN 0002-953X

Cardno, A.G., Marshall, E.J., Coid, B., Macdonald, A.M., Ribchester, T.R., Davies, N.J., Venturi, P., Jones, L.A., Lewis, S.W., Sham, P.C., Gottesman, I.I., Farmer, A.E., McGuffin, P., Reveley, A.M. \& Murray, R.M. (1999). Heritability estimates for psychotic disorders. Maudsley twin psychosis series. Arch Gen Psychiatry, Vol. 56, No.2 , (Feb 1999), pp. 162-168, ISSN 0003-990X

Chang, C.M., Yu, C.C., Lu, H.T., Chou, Y.F. \& Huang, R.F. (2007). Folate deprivation promotes mitochondrial oxidative decay : DNA large deletions, cytochrome $\mathrm{c}$ oxidase dysfunction, membrane depolarisation and superoxide overproduction in rat liver. Br J Nutr, Vol. 97, No. 5, (May 2007), pp. 855-863, ISSN 0007-1145

Chen, J.Q., Delannoy, M., Cooke, C. \& Yager, J.D. (2004). Mitochondrial localization of ERalpha and ERbeta in human MCF7 cells. Am J Physiol Endocrinol Metab, Vol. 286, No. 6, (Jun 2004), E1011-E1022, ISSN 0193-1849

Crepsi, B., Summers, K., Dorus, S. (2007). Adaptive evolution of genes underlying schizophrenia. Proc R Soc B 2007, Vol. 274, No. 1627, (Nov 2007), pp. 2801-2810, ISSN 1471-2954

Crow, T.J. (1995). A Darwinian approach to the origin of psychosis. Brit J Psychiatry, Vol. 167, No. 1, (July 1995), pp. 12-25, ISSN 0007-1250

Dalman, C., Allebeck, P., Gunnell, D., Harrison, G., Kristensson, K., Lewis, G., Lofving, S., Rasmussen, F., Wicks, S. \& Karlsson, H. (2008). Infections in the CNS during childhood and the risk of subsequent psychotic illness: a cohort study of more than one million Swedish subjects. Am J Psychiatry, Vol. 165, No. 1, (Jan 2008), pp. 59-65, ISSN 0002-953X

Dalman, C., Allebeck, P., Cullberg, J., Grunewald, C. \& Köster, M. (1999). Obstetric complications and the risk of schizophrenia. A longitudinal study of a national birth cohort. Arch Gen Psychiatry, Vo. 56, No. 3, (Mar 1999), pp. 234-240, ISSN 0003-990X

Demirhan, O., Tastemir, D. \& Sertdemir, Y. (2006). Chromosomal fragile sites in schizophrenic patients. Genetika, Vol. 42, No. 7, (July 2006), pp. 985-92, ISSN 0016-6758

Doi, N., Hoshi, Y., Itokawa, M., Usui, C., Yoshikawa, T., \& Tachikawa, H. (2009). Persistence criteria for susceptibility genes for schizophrenia - a discussion from an evolutionary view point. PLoS One, Vol. 4, No.11, (Nov 2009), e7799, ISSN 1932-6203

Edlund, C., Holmberg, K., Dallnen, G., Norrby, E. \& Kristensson, K. (1994). Ubiquinone-10 protects neurons from virus-induced degenerations. J Neurochem, Vol. 63, No. 2, (Aug 1994), pp. 634-639, ISSN 1471-4159 
El-Saadi, O., Pedersen, C.B., McNeil, T.F., Saha, S., Welham, J., O'Callaghan, E., CantorGraae, E., Chant, D., Mortensen, P.B. \& McGrath, J. (2004). Paternal and maternal age as risk factors for psychosis: findings from Denmark, Sweden and Australia. Schizophr Res, Vol. 67, No. 2-3, (April 2004), pp. 227-236, ISSN 0920-9964

Erlenmeyer-Kimling, L. (1968). Mortality rates in the offspring of schizophrenic parents and a physiological advantage hypothesis. Nature, Vol. 5169, 220, (Nov 1968), pp. 798800, ISSN 0028-0836

Esposito, L.A., Melov, S., Panov, A., Cottrell, B.A. \& Wallace, D.C. (1999). Mitochondrial disease in mouse results in increased oxidative stress. Proc Natl Acad Sci USA, Vol. 96, No. 9, (Apr 1999), pp. 4820-4825, ISSN 0027-8424

Fãnanás, L. \& Bertranpetit, J. (1995). Reproductive rates in families of schizophrenic patients in a case-control study. Acta Psychiatr Scand, Vol. 91, No. 3, (Mar 1995), pp. 202-204, ISSN 1600-0447

Finkel, T. (2003). Oxidant signals and oxidant stress. Curr Opin Cell Biol, Vol. 15, No.2 , (Apr 2003), pp. 247-254, ISSN 0955-0674

Folgero, T., Storbakk, N., Torbergsen, T. \& Oian, P. (1996). Mutations in mitochondrial transfer ribonucleic acid genes in preeclampsia. Am J Obstet Gynecol, Vol. 174, No. 5, (May 1996), pp. 1626-1630, ISSN 0002-9378

Furui, T., Kurauchi, O., Tanaka, M., Mizutani, .S, Ozawa, T. \& Tomoda, Y. (1994). Decrease in cytochrome c oxidase and cytochrome oxidase subunit I messenger RNA levels in preeclamptic pregnancies. Obstet Gynecol, Vol. 84, No. 2, (Aug 1994), 283-288, ISSN 0029-7844

Goldstein, J.M., Faraone, S.V. \& Chen, W.J., Tolomiczencko, G.S. \& Tsuang, M.T. (1990). Sex differences in the familial transmission of schizophrenia. Br J Psychiatry, Vol. 156, No. 6, (Jun 1990), pp. 819-826, ISSN 0007-1250

Goldstein, J.M. \& Lewine, R.R.J. (2000). Overview of sex differences in schizophrenia: where have we been and where do we go from? In: Women and schizophrenia, Castle, D.L., McGrath, J. \& Kulkarni, J. eds., pp. 111-143, Cambridge University Press, ISBN 978-0521786171, Cambridge

Gottesman, I.I. \& Bertelsen, A. (1989). Confirming unexpressed genotypes for schizophrenia. Risks in the offspring of Fischer's Danish identical and fraternal discordant twins. Arch Gen Psychiatry, Vol. 46, No. 10, (Oct 1989), pp. 867-872, ISSN 0003-990X

Gottesman, I.I. (1991). Schizophrenia Genesis; The Origin of Madness. Freeman \& Company, ISBN 978-0716721475, New York, NY

Gupta, P., Narang, M., Banerjee, B.D. \& Basu, S. (2004). Oxidative stress in term small for gestational age neonates born to undernourished mothers: a case controlled study. BMC Pediatrics, Vol. 4, No. 4, (July 2004), pp. 14-20, ISSN 1471-2431

Harrison, G., Cooper, J.E. \& Gancarczyk, R. (1991). Changes in the administrative incidence of schizophrenia. Br J Psychiatry, Vol. 159, No. 6, (Dec 1991), pp. 811-816, ISSN 0007-1250

Haukka, J., Suvisaari, J., \& Lonnqvist, J. (2003). Fertility of patients with schizophrenia, their siblings, and the general population: a cohort study from 1950 to 1959 in Finland. Am J Psychiatry, Vol. 160, No. 3, (Mar 2003), pp. 460-463, ISSN 0002-953X

Hayashi, M. (1950). A study of schizophrenia. (in Japanese) Psychiatr Neurol Japonica, Vol. 51, No. 3, (Mar 1950), pp.193-245, ISSN 0033-2658

He, L., Perkins, G.A., Poblenz, A.T., Harris, J.B., Hung, M., Ellisman, M.H. \& Fox, D.A. (2003). Bcl- $x_{\mathrm{L}}$ overexpression blocks bax-mediated mitochoncrial contact site 
formation and apoptosis in rod photoreceptors of lead-exposed mice. Proc Natl Acd Sci USA, Vol. 100, No. 3, (Feb 2003), pp. 1022-1027, ISSN 0027-8424

Hitchon, C.A. \& El-Gabalawy, H.S. (2004). Oxidation in rheumatoid arthritis. Arthritis Res Ther,Vol. 6, No. 6, (Oct 2004), pp. 265-278, ISSN 1473-6362

Hussain, S.P., Hofseth, L.J. \& Harris, C.C. (2003). Radical causes of cancer. Nat Rev Cancer, Vol. 3, No. 4, (Apr 2003), pp. 276-285, ISSN 1474-175X

Huxley, J., Mayr, E., Osmond, H. \& Hoffer, A. (1964). Schizophrenia as a genetic morphism. Nature, Vol. 204, No. 4955, (Oct 1964), pp. 220-221, ISSN 0028-0836

Jablensky, A.V. (1995). Schizophrenia: the Epidemiological Horizon. In: Schizophrenia Hirsch, S.R. \& Weinberger, D.R., eds., pp. 206-252, Blackwell Science, ISBN 0-632-03276-6, London

Keller, M.C. \& Miller, G. (2006). Resolving the paradox of common, harmful, heritable mental disorders: Which evolutionary genetic models work best? Behav Brain Sci, Vol. 29, No. 4, (Aug 2006), pp. 385-404, ISSN 0140-525X

Kendler, K.S. \& Dichl, S.R. (1993). The genetics of schizophrenia: a current, geneticepidemiologic perspective. Schizophr Bulletin, Vol. 19, No. 2, (Apr 1993), pp. 261-285 ISSN 0586-7614

Kinney, D.K., Richards, R., Lowing, P.A., LeBranc, D., Morris, E., Zimbalist, M.E., \& Harlan, P. (2001). Creativity in offspring of schizophrenic and control parents: an adoption study. Creativity Research Journal, Vol. 13, No. 1, (Jan 2001), pp.17-25, ISSN 1532-6934

Kirov, G., O'Donovan, M.C., Owen, M.J. (2005). Finding schizophrenia genes. J Clin Invest, Vol. 115, No. 6, (Jun 2005), pp. 1440-1448, ISSN 0021-9738

Kruman, I.I., Culmsee, C., Chan, S.L., Kruman, Y., Guo, Z., Penix, L. \& Mattson, M.P. (2006). Homocysteine elicits a DNA damage response in neurons that promotes apoptosis and hypersensitivity to excitotoxicity. J Neurosci, Vol. 20, No. 18, (Sep 2006), pp. 6920-6026, ISSN 1529-2401

Kulkarni, J. \& Fink, G. (2000). Hormones and psychosis. In: Women and schizophrenia, Castle, D.L., McGrath, J. \& Kulkarni, J. eds., pp. 51-66, Cambridge University Press, ISBN 978-0521786171, Cambridge

Larson, C.A. \& Nyman, G.E. (1973). Differential fertility in schizophrenia. Acta Psychiatr Scand, Vol. 49, No. 3, (Jun 1973), pp. 272-280, ISSN 1600-0447

Limosin, F., Rouillon, F., Payan, C., Cohen, J-M. \& Strub, N. (2003). Prenatal exposure to influenza as a risk factor for adult schizophrenia. Acta Psychiatr Scand, Vol. 107, No. 5, (May 2003), pp. 331-335, ISSN 1600-0447

Li, X., Sundquist, J. \& Sundquist, K. (2007). Age-specific familial risks of psychotic disorders and schizophrenia: a nation-wide epidemiological study from Sweden. Schizophr Res, Vol. 97, No. 1-3, (Dec 2007), pp. 43-50, ISSN 0920-9964

Lo, W.S., Xu, Z., Yu, Z., Pun, F.W., Ng, S.K., Chen, J., Tong, K.L., Zhao, C., Xu, X., Tsang, S.Y., Harano, M., Stöber, G., Nimgaonkar, V.L., \& Xue, H. (2007). Positive selection within the schizophrenia-associated GABA $\mathrm{A}_{\mathrm{A}}$ receptor $\beta_{2}$ gene. PLoS One, Vol. 2, No. 5, (May 2007), e462, ISSN 1932-6203

Macintyre, D.J., Blackwood, D.H.R., Porteous, D.J., Pickard, B.S. \& Muir, W.J. (2003). Chromosomal abnormalities and mental illness. Mol Psychiatry, Vol. 8, No. 3, (Mar 2003), pp. 275-287, ISSN 1359-4184

Malaspina, D., Harlap, S., Fennig, S., Heiman, D., Nahon, D., Feldman, D. \& Susser, E.S. (2001). Advancing paternal age and the risk of schizophrenia. Arch Gen Psychiatry, Vol. 58, No. 4, (Apr 2001), pp. 361-367, ISSN 0003-990X 
Marchbanks, R.M., Mulcrone, J. \& Whatley, S.A. (1995) Aspects of oxidative metabolism in schizophrenia. Brit J Psychiatry, (1995), Vol. 167, No. 3, (Sep 1995), pp.293-298, ISSN 0007-1250

McGrath, J.J., Hearle, J., Jenner, L., Plant, K., Drummond, A. \& Barkla, J.M. (1999). The fertility and fecundity of patients with psychoses. Acta Psychiatr Scand, Vol. 99, No. 6, (Jun 1999), pp. 441-446, ISSN 1600-0447

McGrath, J., Saha, S., Chant, D. \& Welham, J. (2008). Schizophrenia: A concise overview of incidence, prevalence, and mortality. Epidemiologic Reviews, Vol. 30, No. 1, (Nov 2008), pp. 67-76, ISSN 0193-936X

McGue, M. \& Gottesman, I.I. (1991). The genetic epidemiology of schizophrenia and the design of linkage studies. Eur Arch Psychiatry Clin Neurosci, Vol. 240, No. 3, (Feb 1991), pp. 174-181, ISSN 0940-1334

Modrzewska, K. (1980). The offspring of schizophrenic parents in a North Swedish isolate. Clin Genet, Vol. 17, No. 3. (Mar 1980), pp. 191-201, ISSN 1399-0004

Monje, P. \& Boland, R. (2001). Subcellular distribution of native estrogen receptor alpha and beta isoforms in rabbit uterus and ovary. J Cell Biochem, Vol. 82, No. 3, (Sep 2001), pp. 467-479, ISSN 1097-4644

Murphy, K.C., Jones, L.A. \& Owen, M.J. (1999). High rates of schizophrenia in adults with velo-cardio-facial syndrome. Arch Gen Psychiatry, Vol. 56, No. 10, (Oct 1999), pp. 940-945, ISSN 0003-990X

Nachman, M.W. \& Crowell, S.L. (2000). Estimate of the mutation rate per nucleotide in humans. Genetics, Vol. 156, No. 3, (Sept 2000), pp. 297-304, , ISSN 0016-6731

Nanko, S. \& Moridaira, J. (1993). Reproductive rates in schizophrenic outpatients. Acta Psychiatr Scand, Vol. 87, No. 6, (Jun 1993), pp. 400-404, ISSN 1600-0447

Need, A.C., Ge, D., Weale, M.E., Maia, J., Feng, S., Heinzen, E.L., Shianna, K.V., Yoon, W., Kasperaviciūte, D., Gennarelli, M., Strittmatter, W.J., Bonvicini, C., Rossi, G., Jayathilake, K., Cola, P.A., McEvoy, J.P., Keefe, R.S., Fisher, E.M., St Jean, P.L., Giegling, .I, Hartmann, A.M., Möller, H.J., Ruppert, A., Fraser, G., Crombie, C., Middleton, L.T., St Clair, D., Roses, A.D., Muglia, P., Francks, C., Rujescu, D., Meltzer, H.Y. \& Goldstein, D.B. (2009). A Genome-Wide Investigation of SNPs and CNVs in Schizophrenia. PLoS Genet Vol. 5, No. 2, (Feb 2009), e1000373, ISSN 1553-7404

Nimgaonkar, V.L. (1998). Reduced fertility in schizophrenia: here to stay? Acta Psychiatr Scand, Vol. 98, No. 5, (Nov 1998), pp. 348-353, ISSN 1600-0447

Nishikawa, Y., Kawase, O., Vielemeyer, O., Suzuki, H., Joiner, K.A., Xuan, X. \& Nagasawa, H. (2007). Toxoplasma gondii infection induces apoptosis in noninfected macrophages: role of nitric oxide and other soluble factors. Parasite Immunol, Vol. 29, No. 7, (July 2007), pp.375-385, ISSN 0141-9838

Ohashi, J \& Tokunaga, K. (2002). The expected power of genome-wide linkage disequilibrium testing using single nucleotide polymorphism markers for detecting a low-frequency disease variant. Ann Hum Genet, Vol. 66, No. 4, (July 2002), pp. 297-306, ISSN 0003-4800

Ødegård, Ø. (1980). Fertility of psychiatric first admissions in Norway, 1936-1975. Acta Psychiatr Scand, Vol. 62, No. 3, (Sep 1980), pp. 212-220, ISSN 1600-0447

Oken, R.J. \& Schulzer, M. (1999). At issue: schizophrenia and rheumatoid arthritis: the negative association revised. Schizophr Bull, Vol. 25, No.4 , (Oct 1999), pp. 625-638, ISSN 0586-7614 
Opler, M.G.A. \& Susser, E.S. (2005). Fetal environment and schizophrenia. Environment Health Perspectives, Vol. 113, No. 9, (Sep 2005), pp. 1239-1242, ISSN 0091-6765

Osby, U., Hammer, N., Brandt, L., Wicks, S., Thinsz, Z., Ekbom A, Sparén P. (2001). Time trends in first admissions for schizophrenia and paranoid psychosis in Stockholm County, Sweden. Schizophr Res, Vol. 47, No. 2-3, (Mar 2001), pp. 247-254, ISSN 09209964

Pajović, S.B., Saićić, Z.S., Spasić, M.B. \& Petrović, V.M. (2003).The effect of ovarian hormones on antioxidant enzyme activities in the brain of male rats. Physiol Res, Vol. 52, No. 2, (Mar2003), pp. 189-194, ISSN 0826-8404

Poncet, D., Pauleau, A.L., Szabadkai, G., Vozza, A., Scholz, S.R., Le Bras, M., Brière, J.J., Jalil, A., Le Moigne, R., Brenner, C., Hahn, G., Wittig, I., Schägger, H., Lemaire, C., Bianchi, K., Souquère, S., Pierron, G., Rustin, P,. Goldmacher, V.S., Rizzuto, R., Palmieri, F. \& Kroemer G. (2006). Cytopathic effects of cytomegalovirus-encoded apoptosis inhibitory protein vMIA. J Cell Biol, Vol. 174, No. 7, (Sep 2006), pp. 985996, ISSN 0021-9525

Prabakaran, S., Swatton, J.E., Ryan, M.M., Huffaker, S.J., Huang, J.T-J., Griffin, J.L., Wayland, M., Freeman, T., Dudbridge, F., Lilley, K.S., Karp, N.A., Hester, S., Tkachev, D., Mimmack, L., Yolken, R.H., Webster, M.J., Torrey, E.F., \& Bahn, S. (2004). Mitochondrial dysfunction in schizophrenia: evidence for compromised brain metabolism and oxidative stress. Molecular Psychiatry, Vol. 9, No. 7, (July 2004), pp. 684-697, ISSN 1359-4184

Pulver, A.E., Nestadt, G., Goldberg, R., Shprintzen, R.J., Lamacz, M., Wolyniec, P.S., Morrow, B., Karayiorgou, M., Antonarakis, S.E., Housman, D. et al. (1994). Psychotic illness in patients diagnosed with velo-cardio-facial syndrome and their relatives. J Nerv Ment Dis, Vol. 182, No. 8, (Aug 1994), pp. 476-478, ISSN 0022-3018

Ragu, S., Faye, G., Iraqui, I., Masurel-Heneman, A., Kolodner, R.D. \& Huang, M-E. (2007). Oxygen metabolism and reactive oxygen species cause chromosomal rearrangements and cell death. Proc Natl Acad Sci USA, Vol. 104, No. 23, (Jun 2007), pp. 9747-9752, ISSN 0027-8424

Rapoport, J.L., Addington, A.M. \& Fragnau, S. (2005). The neurodevelopmental model of schizophrenia: update 2005. Mol Psychiatry, Vol. 10, No. 5, (May 2005), pp. 434-449, ISSN 1359-4184

Remans, P.H., van Oosterhout, M., Smeets, T.J., Sanders, M., Frederiks, W.M., Reedquist, K.A., Tak, P.P., Breedveld, F.C. \& van Laar, J.M. (2005). Intracellular free radical production in synovial $\mathrm{T}$ lymphocytes from patients with rheumatoid arthritis. Arthritis \& Rheumatism, Vol. 52, No. 7, (July 2005), pp. 2003-2009, ISSN 0004-3591

Rieder, R.O., Rosenthal, D., Wender, P. \& Blumenthal, H. (1975). The offspring of schizophrenics, I: fetal and neonatal deaths. Arch Gen Psychiatry, Vol. 32, No. 2, (Feb 1975), pp. 200-211, ISSN 0003-990X

Risch, N., Reich, E.W., Wishnick, M.M. \& McCarthy, J.G. (1987). Spontaneous mutation and parental age in humans. Am J Hum Genet, Vol. 41, No. 2, (Aug 1987), pp.218-248, ISSN 0002-9297

Rubinstein, G. (1997). Schizophrenia, rheumatoid arthritis and natural resistance genes. Schizophr Res, Vol. 25, No. 3, (Jun 1997), pp. 177-181, ISSN 0920-9964 
Samper, E., Nicholls, D.G. \& Melov, S. (2003). Mitochondrial oxidative stress causes chromosomal instability of mouse embryonic fibroblasts. Aging Cell, Vol. 2, No. 5 , (Oct 2003), pp. 277-285, ISSN 1474-9718

Senoo-Matsuda, N., Yasuda, K., Tsuda, M., Ohkubo, T., Yoshimura, S., Nakazawa, H., Hartman, P.S. \& Ishii, N. (2001). A defect in the cytochrome b large subunit in complex II causes both superoxide anion overproduction and abnormal energy metabolism in Caenorhabditis elegans. J Biol Chem, Vol. 276, No. 45, (Nov 2001), pp. 41553-41558, ISSN 0021-9258

Shanklin, D.R., Sibai, B.M. (1990). Ultrastructural aspects of preeclampsia. II. Mitochondrial changes. Am J Obstet Gynecol, Vol. 163, No. 3, (Sep 1990), pp.943-953, ISSN 00029378

Shimizu, A., Kurachi, M., Yamaguchi, N., Torii, H. \& Isaki K. (1987). Morbidity risk of schizophrenia to parents and siblings of schizophrenic patients. Jpn J Psychiatry Neurol, Vol. 41,No. 1, (Mar 1987), pp. 65-70, ISSN 0912-2036

Sigurđardóttir, S., Helgason, A., Gulcher, J.R., Stefansson, K. \& Donnely, P. (2000). The mutation rate in the human mtDNA control region. Am J Hum Genet, Vol. 66, No. 5, (May2000), pp. 1599-1609, ISSN 0002-9297

Sipos, A., Rasmussen, F., Harrison, G., Tynelius, P., Lewis, G., Leon, D.A. \& Gunnell, D. (2004). Paternal age and schizophrenia; a population based cohort study. BMJ, Nov 6; 329(7474):1070. Epub 2004 Oct 22, ISSN 1468-5833

Smith, C.L., Bolton, A. \& Nguyen, G. (2010). Genomic and epigenomic instability, fragile sites, schizophrenia and autism. Current Genomics, Vol. 11, No. 6, (Sep 2010), pp. 447-469, ISSN 1389-2029

Sobel, D. E. (1961). Infant mortality and malformations in children of schizophrenic women. Psychiatr Q, Vol. 35, No. 1, (Mar 1961), pp. 60-65, ISSN 0033-2720

Speir, E., Yu, Z.X., Ferrans, V.J., Huang, E.S. \& Epstein, S.E. (1998). Aspirin attenuates cytomegalovirus infectivity and gene expression mediated by cyclooxigenase-2 in coronary artery smooth muscle cells. Circ Res, Vol. 83, No. 2, (July 1998), pp. 210 216, ISSN 0009-7330

Stabeneau, J.R., Pullin, W., Moshe, R.L.R., Froman, C., Friedhoff, A.J., \& Turner, W. (1969). Study of monozygotic twins discordant for schizophrenia. Some biologic variables. Arch Gen Psychiatry, Vol. 20, No. 2, (Feb 1969), pp. 145-158, ISSN 0003-990X

Stirone, C., Duckles, S.P., Krause, D.N. \& Procaccio, V. (2005). Estrogen increases mitochondrial efficiency and reduces oxidative stress in cerebral blood vessels. Mol Pharmacol, Vol. 68, No. 4, (Oct 2005), pp.959-965, ISSN 0026-895X

Strehlow, K., Rotter, S., Wassmann, S., Adam, O., Grohé, C., Laufs, K., Böhm, M. \& Nickenig, G. (2003). Modulation of antioxidant enzyme expression and function by estrogen. Circ Res, Vol. 93, No. 2, (July 2003), pp. 170-173, ISSN 0009-7330

Susser, E., Neugebauer, R., Hoek, H.W., Brown, A.S., Lin, S., Labovitz, D. \& Gorman, J.M. (1996). Schizophrenia after prenatal famine. Further evidence. Arch Gen Psychiatry, Vol. 53, No. 1, (Jan 1996), pp. 25-31, ISSN 0003-990X

Svensson, A.C., Lichtenstein, P., Sandin, S. \& Hultman, C.M. (2007). Fertility of first-degree relatives of patients with schizophrenia: A three generation perspective. Schizophr Res, Vol. 91, No. 1-3, (Mar 2007), pp. 238-245, ISSN 0920-9964 
Takahashi, Y. (1953). An enzymological study on brain tissue of schizophrenic patients. Carbohydrate metabolism. Folia Psychiatrica Neurologica Japonica, Vol. 7, No. 3, (Dec 1953), pp. 214-269, ISSN 0015-5721

Torbergsen, T., Oian, P., Mathiesen, E. \& Borud, O. (1989). Pre-eclampsia - A mitochondrial disease? Acta Obstet Gynecol Scand, Vol. 68, No. 2, (Feb 1989), pp. 145-148, ISSN 0001-6349

Utena, H. \& Ezoe, T. (1951). Studies on the carbohydtrate metabolism in brain tissues of schizophrenic patients. II. Report. (in Japanese, with English abstract) Psychiatr Neurol Japonica, Vol. 52, No. 3, (Mar 1951), pp. 216-232, ISSN 0033-2658

Utena, H. \& Niwa, S. (1992). The history of schizophrenia research in Japan. Schizophr Bull, Vol. 18, No. 1, (Jan 1992), pp. 67-73, ISSN 0586-7614

Valero, J., Martorell, L., Marine, J., Vilella, E., \& Labad, A. (1998). Anticipation and imprinting in Spanish families with schizophrenia. Acta Psychiatr Scand, Vol. 97, No. 5, (May 1998), pp. 343-350, ISSN 1600-0447

Vinogradov, S., Gottesman, I.I., Moises, H.W. \& Nicol, S. (1991). Negative associaton between schizophrenia and rheumatoid arthritis. Schizophr Bull, Vol. 17, No. 4, (Oct 1991), pp. 669-678, ISSN 0586-7614

Wang, J., Wu, J. \& Zhang, Z. (2006). Oxidative stress in mouse brain exposed to lead. Ann Occup Hyg, Vol. 50, No. 4, (Jun 2006), pp. 405-409, ISSN 0003-4878

Walsh, T., McClellan, J.M., McCarthy, S.E., Addington, A.M., Pierce, S.B., Copper, G.M., Nord, A.S., Kusenda, M., Malhortra, D., Bhandari, A., Stray, S.M., Rippery, C.F., Roccanova, P., Makarov, V., Lakshmi, B., Finling, R.L., Sikich, L., Stromerg, T., Merriman, B., Gogtay, N., Butler, P., Eckstrand, K., Noory, L., Gochman, P., Long, R., Chen, Z., Davis, S., Baker, C., Eichler, E.E., Meltzer, P.S., Nelson, S.F., Singleton, A.B., Lee, M.K., Rapoport, J.L., King, M.C., Sebat, J. (2008). Rare structural variants disrupt multiple genes in neurodevelopmental pathways in schizophrenia. Science, Vol. 320, No.5875 , (Apr 2008), pp. 539-43, ISSN 0036-8075

Webb, R., Abel, K., Pickles, A. \& Appleby, L. (2005). Mortality in offspring of parents with psychotic disorders: a critical review and meta-analysis. Am J Psychiatry, Vol. 162, No.6, (Jun 2005), pp. 1045-56, ISSN 002-953X

Wood, S.J., Yücel, M., Pantelis, C., \& Berk, M. (2009). Neurobiology of schizophrenia spectrum disorders: the role of oxidative stress. Ann Acad Med Singapore, Vol. 38, No. 5, (May 2009), pp. 396-401, ISSN 1145745

Xu, B., Roos, J.L., Levy, S., van Rensburg, E.J., Gogos, J.A. \& Karayiorgou, M. (2008). Strong association of de novo copy number mutations with sporadic schizophrenia. Nat Genet, Vol. 40, No. 7, (July 2008),pp. 880-885, ISSN 1546-1718

Zaki, M.H., Akutu, T., \& Akaike, T. (2005). Nitric oxide-induced nitrative stress involved in microbial pathogenesis. J Pharmacol Sci, Vol. 98, No. 2, (Jun 2005), pp. 117-129, ISSN 1347-8613

Zammit, S., Allebeck, P., Dalman, C., Lundberg, I., Hemmingson, T., Owen, M.J, \& Lewis, G. (2003). Paternal age and risk for schizophrenia. Brit J Psychiatry, Vol. 183, No. 5, (Nov 2003), pp. 405-408, ISSN 0007-1250 


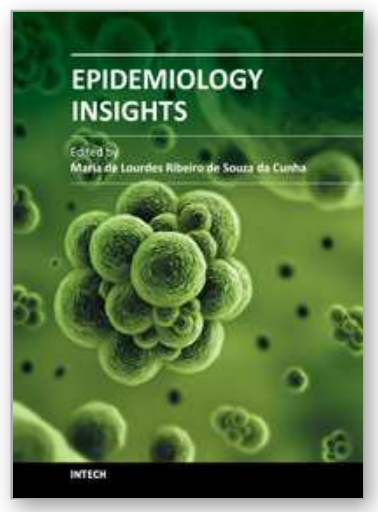

\author{
Epidemiology Insights \\ Edited by Dr. Maria De Lourdes Ribeiro De Souza Da Cunha
}

ISBN 978-953-51-0565-7

Hard cover, 396 pages

Publisher InTech

Published online 20, April, 2012

Published in print edition April, 2012

This book represents an overview on the diverse threads of epidemiological research, brings together the expertise and enthusiasm of an international panel of leading researchers to provide a state-of-the art overview of the field. Topics include the epidemiology of dermatomycoses and Candida spp. infections, the epidemiology molecular of methicillin-resistant Staphylococcus aureus (MRSA) isolated from humans and animals, the epidemiology of varied manifestations neuro-psychiatric, virology and epidemiology, epidemiology of wildlife tuberculosis, epidemiologic approaches to the study of microbial quality of milk and milk products, Cox proportional hazards model, epidemiology of lymphoid malignancy, epidemiology of primary immunodeficiency diseases and genetic epidemiology family-based. Written by experts from around the globe, this book is reading for clinicians, researchers and students, who intend to address these issues.

\title{
How to reference
}

In order to correctly reference this scholarly work, feel free to copy and paste the following:

Nagafumi Doi, Yoko Hoshi, Masanari Itokawa, Takeo Yoshikawa and Tomoe Ichikawa (2012). Impact of Epidemiology on Molecular Genetics of Schizophrenia, Epidemiology Insights, Dr. Maria De Lourdes Ribeiro De Souza Da Cunha (Ed.), ISBN: 978-953-51-0565-7, InTech, Available from:

http://www.intechopen.com/books/epidemiology-insights/impact-of-epidemiology-on-molecular-genetics-ofschizophrenia

\section{INTECH}

open science | open minds

\section{InTech Europe}

University Campus STeP Ri

Slavka Krautzeka 83/A

51000 Rijeka, Croatia

Phone: +385 (51) 770447

Fax: +385 (51) 686166

www.intechopen.com

\section{InTech China}

Unit 405, Office Block, Hotel Equatorial Shanghai

No.65, Yan An Road (West), Shanghai, 200040, China

中国上海市延安西路65号上海国际贵都大饭店办公楼 405 单元

Phone: +86-21-62489820

Fax: $+86-21-62489821$ 
(C) 2012 The Author(s). Licensee IntechOpen. This is an open access article distributed under the terms of the Creative Commons Attribution 3.0 License, which permits unrestricted use, distribution, and reproduction in any medium, provided the original work is properly cited. 